RECEIVED: NOVEMBER 2014

REVISED: JUNE 2015

ACCEPTED: JUNE 2015

DOI: 10.1515/ngoe-2015-0014

UDK: $657.6(497.4)$

JEL: M19
ORIGINAL SCIENTIFIC PAPER

\section{Controllership Influences on the Restructuring of Slovenian Companies}

\author{
Danijel Lebar \\ Gregorčičeva ulica 1, 9231 Beltinci, Slovenia \\ danijel.lebar@gmail.com \\ Iztok Kolar \\ University of Maribor, Faculty of Economics and Business, Slovenia \\ iztok.kolar@um.si
}

\begin{abstract}
Controllership, as an informational activity, is becoming a multidimensional function, about which numerous doubts exist as to whether to increase its independency and integrate it tightly with the decision-making process. Financial knowledge and business-analytical capabilities of carriers of controllership activity can offer support for operational, financial, and strategic restructuring. This is important when facing frequent business dynamics in order to enhance competitiveness and especially achieve short-term as well as strategic goals.
\end{abstract}

Keywords: controllership, controller, restructuring, financial knowledge, businessanalytical capabilities.

\section{Defining the Problem}

In the process of searching for the right solutions for restructuring Slovenian companies, there is a priority objective to improve their ability to react to problems appropriately based on the existing challenges, such as optimizing unprofitable production and sales programs, reversing negative financial and business trends, and finding solutions for overly fragmented and diversified investment programs. Senior management is trying to achieve turnaround in business performance and efficiency through restructuring in order to enhance stability in the process of business development, representing fundamentals for ongoing existence and the development of individual companies (Altman \& Hotchkiss, 2006).

\section{NG OE}

NAŠE GOSPODARSTVO OUR ECONOMY

\section{Vol. 61 No.4 2015}

pp. 14- 22
In this context modern designed controllership also plays a role as it is becoming an activity with multidimensional jurisdictions and obligations. The majority of its traditional tasks have become automized, leaving room to integrate its working field with business analytics, strategic planning, and internal consultancy. All this can contribute to incorporating it more into a company's strategic management (Smith \& Graves, 2005).

Zoni and Merchant (2007) noted that companies hesitate when deciding whether to integrate controllership tightly with the process of operational and strategic management decision making. On the other hand, Mass (2007) emphasized that the inclusion of active controllership in the process of management's decision making by itself does not bring about the desired results and synergies. 
Among the critical factors for successful restructuring and a company's turnaround, some authors (e.g., Zoni \& Merchant, 2007) have also included financial knowledge and business analytical competencies of employees who work on the field of controllership. We try to find an answer about how the identified individual factors of controllership influence the overall success of the restructuring process in Slovenian companies and to compare findings with foreign research.

\section{Hypotheses}

Based on our initial questions and the research of Zoni and Marchant (2007) and Mass (2007), we formed the following hypotheses:

$\mathrm{H}_{1}$ : The success of a company's restructuring process is connected with the level of financial knowledge held by the controller.

$\mathrm{H}_{2}$ : The better the business analytical competencies of the controller are, the greater the possibility for success of a company's restructuring process.

\section{Theoretical Review of Literature}

Lindhart and Sundqvist (2004) asserted that controllership has recently gone through dynamic changes in reporting, personal responsibility, and its influence on a company's long-term financial position. According to Melavc and Novak (2007), the controller's activity is focused on objectives and provides professional support to management in enhancing business profitability and economics. They explained that controllership is divided according to roles and strategic assignments. Its fundamental role is to provide professional support to increase business efficiency and profitability as well as maintain the company's long-term liquidity and capital adequacy. It further helps with formulating proposals of business measures that can help in management decision making (Perovič, Neradžić, \& Todorović, 2012). Zoni and Merchant (2007) and Mass (2007) defined controllership as an integral part of financial-informational activity in evaluating business programs through performance and profitability. Dimov and Iliev (2010) saw its role from the view of internal consultancy, which can help management develop the company's mission, fundamental objectives, and strategies. Furthermore, controllership plays a role in identifying discrepancies between realized costs and budgeted costs and can help build fast responses in the managerial decision-making process by assembling coherent reports, which represent the most essential input. Nevertheless, Thammatucharee (2011) explained that the purpose of controllership is establishing and ensuring well-performing internal controls. Such assignments are also related with monitoring the internal reporting system, where a sequence of duties, authorities, and responsibilities of employees are crucial for driving optimal information cycles through different organizational and managerial levels. In research, we define this as an informational activity for which process information promotes effective and efficient management decision making.

Restructuring (Keidel, 1994) connects with comprehensive directed changes, which are carried out with greater intensity in a short time and are also riskier for overall turnaround processes. According to Bowman and Singh (1993), reorganizing or downsizing units and layoffs of employees typically refers to activity within the economic framework whose purpose is to provide the organization's survival as a whole. Restructuring usually cannot be performed only in a particular field or function inside the company, but in coordinated changes of multiple structures that can help manage crises at a more comprehensive and efficient level. Yet Schmitt (2009) emphasized that there is a greater risk for a company to go bankrupt, and then more activities must follow in order to improve its financial position. Pearce and Robbins (2008) approached restructuring from its strategic role that must be based on decisions for which organizational and business parts are essential for a company's ongoing business, development breakthroughs, and future existence. Such an approach required defining the "healthy core" of the business in order to empower its resources and capabilities accordingly with the challenges of the economic crisis. In our case, we connected it with radical changes on the strategic level that can lead to long-term business stability, especially in Slovenian companies. Dubrovski (2011) associated the restructuring process with implementing changes in the field of program, innovation, production and reporting processes, where those dimensions represent the main core of restructuring operations; from this point, measures must be taken comprehensively on all the aforementioned fields.

\section{Research: Sample and sampling methods}

The sampling procedure in our research was executed based on the following criteria, which are logically connected with Zoni and Merchant's (2007) and Mass's (2007) research:

- The companies included are Slovenian companies with headquarters in Slovenia and Slovenian or foreign ownership that are doing business in Slovenia and are led by Slovenian management. 
- The companies have a developed system of governance and well-defined management hierarchy.

- Within the companies, controllership is established either as an independent department or under the governance of other departments.

Selection criteria for identifying companies in the sampling process were applied regardless of whether regional headquarters were established within Slovenia or the stock market quotes of the company's shares. However, entrepreneurs, small firms with less developed governance and defined organizational structures, and those companies outsourcing the controllership activity were excluded. From this point of view, we might not be able to generalize the results to the whole population of Slovenian companies based on the sampling criteria restrictions. Data on the samples were obtained from the websites of the Agency of the Republic of Slovenia for Public Legal Records and Related Services, the Slovenian phone book, and the companies themselves. Information were also gathered through a structural questionnaire, whose validation was done with the help of a correlation matrix for structurized factors, which demonstrated the strength of their interdependencies and influential significance. The sample included 40 companies; each received two questionnaires. Thus, approximately 80 questionnaires were sent by e-mail: 40 to employees overseeing controllership and recipients of its reports (chief executive officer, members of the board of directors, and senior management) and 40 to employees actively executing the tasks of controllership, known as controllers. The questionnaire response rate was 22 (27.5\%), which means those questionnaires were correctly fulfilled and properly returned; these included 14 (35\%) controllers and 8 (20\%) management staff. It is a small sample, so this research is considered a pilot project. All data were analyzed using the SPSS program.

The sample comprised 59\% men and $41 \%$ women. The majority of them (68\%) were between the ages of 34 and 51. In addition, $64 \%$ of them had obtained college or university degrees. Furthermore, $45 \%$ of companies deal with food processing or the production of materials, $18 \%$ with sales and marketing activities, and $14 \%$ with financial business. In terms of regional location, $23 \%$ of companies in the sample are from the Central Slovenian region and $14 \%$ are from the Zasavje region. The most common defined working title was member of board of senior management (23\%), followed by chief financial officer and controllers (14\%).

Zoni and Merchant (2007), in their research, presented the main purpose for including controllership more often in management's decision-making process. They also tried to identify how individual factors influence controllership's integration with the decision-making process and whether connections are statistically significant in terms of business success. Their research was conducted on a population of Italian companies using an already-made structural questionnaire. The sampling selection was based on criteria to include companies:

- $\quad$ whose annual income did not exceed 150 million €;

- connected with industry, where those with service activities were excluded; and

- that have headquarters in Italy, are in Italian ownership, and are led by Italian management.

As a result of the selection criteria, 22 of the 30 companies in the sample (73\%) confirmed participation in research. Two questionnaires were sent to each participating company, resulting in 44 questionnaires being sent: 22 to employees in controllership activities and 22 in senior management. Of these, 17 questionnaires (77\%) were correctly completed and returned from controllers and 14 (64\%) from senior management.

Mass (2007) addressed a similar problem from a different perspective. He referred to the connection between controllers' involvement in management processes with the performance measurement system of the individual company. In this study, 314 interviewees were included in selection and 123 (39.17\%) fully participated: 80.3\% men and $19.7 \%$ women. The average age of interviewees was 37. The average length of work experience was 5.6 years in the present position and 7.4 years in control overall. Among the included companies, 29.3\% were in manufacturing and $25.2 \%$ in financial business. Questionnaires were sent by e-mail. Their content was divided into five themes that measured the influence of factors on a 7-point Likert scale. Sampling criteria focused on a population of controllers who have officially recognized certificates and professional titles. Among the 121 participants in the survey who defined their education, $51.5 \%$ were certified public accountants and $48 \%$ had obtained a certified controller certificate. Non-profit companies were excluded from the selection.

\section{Findings and Discussion}

In modern society, formal education plays a great role as it defines the controllership's financial knowledge. Nevertheless, it often seems that complex practical economic issues are quite different from theoretical backgrounds (Smith, 2005).

$\mathrm{H}_{1}$ : The success of a company's restructuring process is connected with the level of financial knowledge held by controllership carriers. 
Controllership carriers' (controllers) financial knowledge is an independent variable defined by the following factors:

- level of financial education

- $\quad$ experience with a company's financial turnaround

- use of financial tools

- involvement in a system of financial risk management

- understanding of the role of solvency and financial liquidity

- $\quad$ evaluation of the financial performance of investments

- management of the cash flow of sectors or organizational units

- maintenance of budget constraints

- markets' macroeconomics and profitability

We tested the first hypothesis using factor analysis because we wanted to discover interdependencies among the factors, defining controllers' financial knowledge. We assumed that level of financial knowledge have a major impact on the overall restructuring performance, what is similar to the research done by Zoni and Merchant (2007).

Table 1. Kaiser-Meyer-Olkin Measure and Bartlett's Test of Sphericity of First Hypothesis

\begin{tabular}{llr}
\hline Kaiser-Meyer-Olkin Sampling Adequacy & .594 \\
\hline \multirow{3}{*}{ Bartlett's test of Sphericity } & adjusted chi-square & 65.317 \\
\cline { 2 - 3 } & degrees of freedom & 45 \\
\cline { 2 - 3 } & significance & .025 \\
\hline
\end{tabular}

Source: Authors’ research

The Kaiser-Meyer-Olkin index gives analytical information about connections between variables and whether using a factor analysis is reasonable from a methodical point of view. When its value is above 0.5 , then usefulness of the factor analysis is reasonable, and we can reject the null hypothesis. This is similar to Bartlett's test, where we can reject the null hypothesis with a risk under the 0.05 threshold, saying that the correlation matrix is not the same as the matrix of a particular unit. In this case, risk is smaller than 0.05 (0.025), meaning that we confirmed the research hypothesis that controllers' financial knowledge influences the company's restructuring performance.

In our case, four factors have an eigenvalue above 1 . These factors explain the majority (74.787\%) of controllers' financial knowledge influence on restructuring. As previously mentioned, the purpose of the factor analysis is to reduce the previous number of variables on a specific number of factors. As shown in Table 2, the first factor represents financial education and has the highest eigenvalue of 3.340, thus explaining $33.403 \%$ of the total variance. This means that this factor contributes the most when it comes to explaining the connection with the overall performance of the company's turnaround. The second factor represents experience with a company's financial turnaround, which explains $15.840 \%$ of the variance not explained by the first factor. Controllers' financial knowledge cumulative explained $49.243 \%$ of those two factors of influence on the success of the implemented structural programs.

Varimax method interdependencies between factors were eliminated in order to present the influence of a particular factor by using so-called factor weights. A higher value indicates more influence associated with an individual variable when it comes to explaining the total variance between the controller's financial knowledge and company's restructuring performance. After the rotation, the four most important

Table 2. Eigenvalue Analysis of Controllership's Financial Knowledge

\begin{tabular}{lcccccc}
\multirow{2}{*}{ Component } & \multicolumn{3}{c}{ Eigenvalue } & \multicolumn{3}{c}{ Extraction sums of squared loadings } \\
\cline { 2 - 7 } & absolute & \% variance & cumulative $\%$ & absolute & \% variance & cumulative \% \\
\hline 2 & 3.340 & 33.403 & 33.403 & 3.340 & 33.403 & 33.403 \\
\hline 3 & 1.584 & 15.840 & 49.243 & 1.584 & 15.840 & 49.243 \\
\hline 4 & 1.358 & 13.584 & 62.827 & 1.358 & 13.584 & 62.827 \\
\hline 5 & 1.196 & 11.961 & 74.787 & 1.196 & 11.961 & 74.787 \\
\hline 6 & .781 & 7.806 & 82.593 & & & \\
\hline 7 & .574 & 5.743 & 88.336 & & & \\
\hline 8 & .466 & 4.664 & 93.000 & & & \\
\hline 9 & .313 & 3.132 & 96.132 & & & \\
\hline 10 & .220 & 2.203 & 98.335 & & & \\
\hline
\end{tabular}

Source: Authors’ research 
factors explained $74.787 \%$ of the total variance. In our case, the level of financial education (-0.780) and financial risk management (0.766) have relatively high factor weight values. After the rotation, the first factor, financial education, explained $22.338 \%$ of the total variance. The second factor, experience with crisis issues, has high weights in connection with markets' macroeconomics and profitability (0.869) and the maintenance of budget constraints (0.766). After rotation, it explained $19.353 \%$ of the total variance. The third factor, use of financial tools, has high factor weight values at searching for alternative financial sources (0.855) and the use of financial tools (-0.763), explaining $19.254 \%$ of the total

Table 3. Factor Weights Extracted with Varimax Method

\begin{tabular}{|c|c|c|c|c|}
\hline & \multicolumn{4}{|c|}{ Component } \\
\hline & 1 & 2 & 3 & 4 \\
\hline Financial education & -.780 & .062 & -.094 & .434 \\
\hline Experience with crisis issues & .742 & .302 & -.167 & .269 \\
\hline Use of financial tools & -.096 & .148 & -.763 & -.170 \\
\hline Managing financial risk & .766 & -.003 & .376 & .087 \\
\hline Solvency and financial liquidity & -.013 & -.083 & .008 & .920 \\
\hline Financial performance of investments & .605 & .506 & .074 & -.303 \\
\hline Managing cash flow of sectors or units & .320 & .412 & .614 & -.317 \\
\hline Maintenance of budget constraints & .071 & .766 & .212 & .091 \\
\hline Help searching for alternative financial sources & -.005 & .211 & .855 & -.122 \\
\hline Markets' macroeconomics and profitability & .082 & .869 & -.083 & -.160 \\
\hline
\end{tabular}

Source: Authors' research

Table 4. Correlation Matrix of Controllers Financial Knowledge with Companies' Restructuring

\begin{tabular}{|c|c|c|c|c|c|c|c|c|c|c|c|}
\hline & & 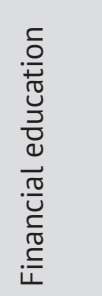 & 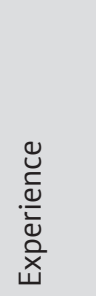 & 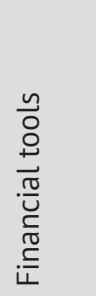 & 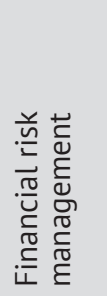 & 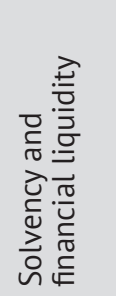 & 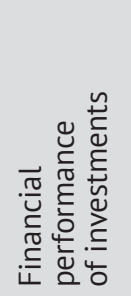 & 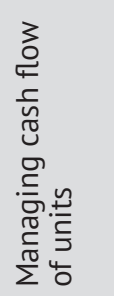 & 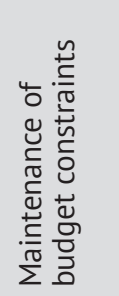 & 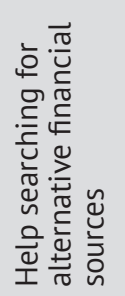 & 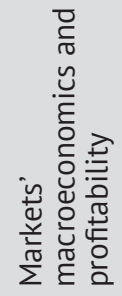 \\
\hline \multirow{10}{*}{ Correlation } & Financial education & 1.000 & -.417 & .178 & -.444 & .361 & -.558 & -.325 & -.086 & -.119 & -.079 \\
\hline & Experience & -.417 & 1.000 & -.046 & .414 & .078 & .356 & .123 & .231 & -.038 & .338 \\
\hline & Financial tools & .178 & -.046 & 1.000 & -.188 & -.078 & .015 & -.227 & -.125 & -.481 & .130 \\
\hline & $\begin{array}{l}\text { Financial risk } \\
\text { management }\end{array}$ & -.444 & .414 & -.188 & 1.000 & .068 & .439 & .551 & .126 & .280 & -.005 \\
\hline & $\begin{array}{l}\text { Solvency and } \\
\text { financial liquidity }\end{array}$ & .361 & .078 & -.078 & .068 & 1.000 & -.216 & -.269 & -.054 & -.098 & -.206 \\
\hline & $\begin{array}{l}\text { Financial } \\
\text { performance of } \\
\text { investments }\end{array}$ & -.558 & .356 & .015 & .439 & -.216 & 1.000 & .501 & .375 & .203 & .488 \\
\hline & $\begin{array}{l}\text { Managing cash flow } \\
\text { of units }\end{array}$ & -.325 & .123 & -.227 & .551 & -.269 & .501 & 1.000 & .366 & .584 & .361 \\
\hline & $\begin{array}{l}\text { Maintenance of } \\
\text { budget constraints }\end{array}$ & -.086 & .231 & -.125 & .126 & -.054 & .375 & .366 & 1.000 & .220 & .437 \\
\hline & $\begin{array}{l}\text { Help searching for } \\
\text { alternative financial } \\
\text { sources }\end{array}$ & -.119 & -.038 & -.481 & .280 & -.098 & .203 & .584 & .220 & 1.000 & .166 \\
\hline & $\begin{array}{l}\text { Markets' } \\
\text { macroeconomics } \\
\text { and profitability }\end{array}$ & -.079 & .338 & .130 & -.005 & -.206 & .488 & .361 & .437 & .166 & 1.000 \\
\hline
\end{tabular}

Source: Authors’ research 
variance after the rotation. The fourth factor, financial risk management, is relatively strongly connected with understanding the role of solvency and financial liquidity (0.920).

The correlation between professional financial education and experience with challenges of crisis showed a negative sign $(-0.417)$ and is relatively strong. The explanation for this fact can be found in discrepancies between theoretical solutions and real economic issues that professionals in control functions face nowadays. Similarly, in the correlation between financial risk management and professional financial education, we see a negative sign (-0.444). In both of these cases, professional education represents fundamentals for gaining experience for dealing with challenges and solving issues of economic crises. It is also important for implementing control and surveillance over the company's risk management system. Experience from crisis management can lead to opportunities for improving the structure of surveillance over financial risk, which can be seen from the correlation $(0.414)$. The controllership's role is compatible with its capability for evaluating the financial performance of investments. This concrete correlation has a positive sign 0.439 ; thus, it can lead to such an interpretation. A more profound correlation (0.551) exists in relation with financial risk and cash flow management.

Zoni and Merchant (2007) noted that a 0.560 correlation exists between controllership carriers' financial knowledge and the needs of Italian management decision-making process. In addition, the correlation between the controllership's integration and a company's performance was confirmed. Performance was evaluated through the operating margin (0.200) and net profit margin for the previous fiveyear period (0.580).

\section{Empirical Analysis of Controllership's Business Analytical Capabilities and Its Influence on the Process of Restructuring}

Controllership and its abilities are becoming the informational basis for building and managing the company's intellectual capital. Its values lie in discovering new, innovative business concepts that can provide a stable market position and sufficient operating flexibility in dealing with business challenges (Thammatucharee, 2011).

$\mathrm{H}_{2:}$ The better business analytical competencies of controllership carriers are, the greater the possibility for success in the company's restructuring process.

For this hypothesis, our main assumption is the positive correlation among the included variables. The chances for successful restructuring represent the dependent variable, although it can go in the opposite direction, where successful restructuring can influence the improvement of the controller's business analytical abilities. These are expressed through individual factors, such as:

- business forecasts;

- $\quad$ use of analytical tools;

- marketing and development business perspective;

- $\quad$ simulations of the reorganizational process;

- causal correlations among the measures adopted;

- $\quad$ informational flow management;

- $\quad$ reports for strategic management;

- $\quad$ evaluations of cost efficiency;

- avoidance of conflict situations; and

- creative solving problems.

The use of factor analysis is reasonable and useful for testing the influence of controllers' business analytical abilities in the success of restructurings. This can be seen from the Keiser-Meyer-Olkin index, which is above the 0.5 threshold. In addition, the level of significance is 0.012 , which means there is a $1.2 \%$ of risk that indicated that differences among variables are not a result of their causal connection during the analytical evolution.

Making business forecasts was the first factor and had the highest eigenvalue, which helps define the variance of each individual factor. The first factor explains $33.443 \%$ of the total variance when it comes to defining its correlation with successful outcomes of overall restructuring process. The next factor is the use of analytical tools; its eigenvalue is 1.698 and it explains $16.976 \%$ of the variance not explained by the first factor. On a cumulative basis, these factors together explained $50.419 \%$ of the total variance. The third factor, making simulations of reorganizational processes, explained $11.980 \%$ of the variance.

The first factor (making business forecasts) has a high factor weight at marketing and development business perspective (0.911) and defines $21.451 \%$ of the total variance after rotation. The use of analytical tools represents the second factor and has high weights at creative solving problems (0.824) and avoiding conflict situations (0.813); this factor defined $20.644 \%$ of the variance after rotation.

Table 5. Kaiser-Meyer-Olkin Measure and Bartlett's Test of Sphericity Test of Second Hypothesis

Kaiser-Meyer-Olkin Sampling Adequacy .591 adjusted chi-square $\quad 69.111$

Bartlett's test of Sphericity

\begin{tabular}{lr}
\hline degrees of freedom & 45 \\
\hline significance & .012
\end{tabular}

Source: Authors’ research 
Table 6. Eigenvalue Analysis of Controllers' Business-analytical Abilities

\begin{tabular}{lcccccc}
\multirow{2}{*}{ Component } & \multicolumn{3}{c}{ Eigenvalue } & \multicolumn{3}{c}{ Extraction sums of squared loadings } \\
\cline { 2 - 7 } 1 & absolute & \%variance & cumulative\% & absolute & \% variance & cumulative\% \\
\hline 2 & 3.344 & 33.443 & 33.443 & 3.344 & 33.443 & 33.443 \\
\hline 3 & 1.698 & 16.976 & 50.419 & 1.698 & 16.976 & 50.419 \\
\hline 4 & 1.420 & 14.196 & 64.615 & 1.420 & 14.196 & 64.615 \\
\hline 5 & 1.198 & 11.980 & 76.596 & 1.198 & 11.980 & 76.596 \\
\hline 6 & .763 & 7.629 & 84.225 & & & \\
\hline 7 & .478 & 4.781 & 89.005 & & & \\
\hline 8 & .426 & 4.262 & 93.267 & & & \\
\hline 9 & .264 & 2.638 & 95.905 & & & \\
\hline 10 & .222 & 2.220 & 98.125 & & & \\
\hline
\end{tabular}

Source: Authors' research

Table 7. Factor Weights Extracted with Varimax Method

\begin{tabular}{lllll} 
& \multicolumn{1}{l}{ Component } & & \\
\cline { 2 - 5 } & 1 & 2 & 3 & 4 \\
\hline Making business forecasts & .020 & .134 & .031 & .930 \\
\hline Use of analytical tools & .454 & -.407 & .425 & .429 \\
\hline Marketing and development business perspective & .911 & -.017 & .096 & -.167 \\
\hline Making simulations at reorganizational process & .749 & .163 & .116 & .438 \\
\hline Causal correlations between taken measures & .646 & .570 & .125 & .056 \\
\hline Informational flow management & .306 & .395 & .520 & .136 \\
\hline Reporting for strategic managing & .107 & -.048 & .789 & .228 \\
\hline Evaluating cost efficiency & .027 & .172 & .854 & -.225 \\
\hline Avoiding conflict situations & -.031 & .813 & -.075 & .346 \\
\hline Creative solving problems & .154 & .824 & .265 & -.135 \\
\hline
\end{tabular}

Source: Authors' research

The marketing and development business perspective is a research field, which is the third factor, and has high values at evaluating cost efficiency (0.854) and reporting the needs of strategic management (0.789); it defines $19.183 \%$ of the total correlation between controllers' business analytical abilities and restructuring performance. Making simulations at the reorganizational process is last the most influential factor with a high value at making business forecasts (0.930). This factor defines $15.318 \%$ of the total variance after rotation.

In comparing the interdependencies among the individual factors, it can be seen that making business forecasts is statistically correlated with simulations and their execution in the process of a company's reorganization. This correlation is also confirmed as statistically significant (0.399), which is relatively weak. Yet this connection can enhance added value when it comes to making simulations for the needs of restructuring the number of jobs and optimizing governance structures. In order to decrease potential risks that can derive from incorrect business forecasts and predictions, which can lead to inappropriate decisions, management can help with simulation tools, which had a relatively strong correlation intensity (0.583). Making simulations is correlated with causal connections among measures whose execution prioritized business stability (sig $=0.008$ ). Making simulations in reorganizational processes is positively correlated (0.527) with causal connections among measures, which play a key role in reversing negative financial and business trends. Avoiding conflict situations has a positive influence (0.537) on creative problem solving.

Mass (2007) noted that the controllership's integration in management's decision-making process is positively 
Table 8. Correlation Matrix of Influence of Controllers' Business-analytical Abilities on Restructuring Performance

\begin{tabular}{|c|c|c|c|c|c|c|c|c|c|c|c|}
\hline & & 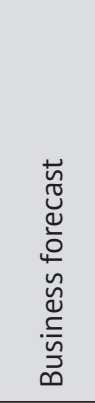 & 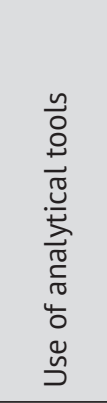 & 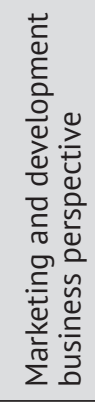 & 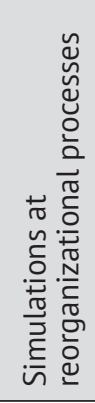 & 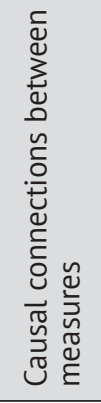 & 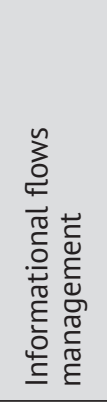 & 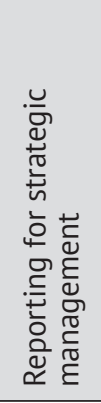 & 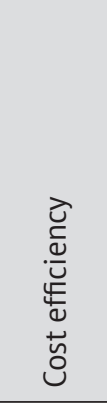 & 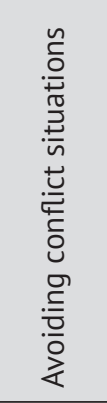 & 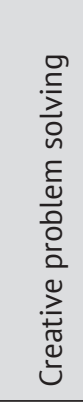 \\
\hline \multirow{10}{*}{ Correlation } & Business forecast & 1.000 & .272 & -.084 & .399 & .189 & .190 & .239 & -.131 & .337 & .000 \\
\hline & $\begin{array}{l}\text { Use of analytical } \\
\text { tools }\end{array}$ & .272 & 1.000 & .331 & .428 & .103 & .348 & .360 & .161 & -.160 & -.135 \\
\hline & $\begin{array}{l}\text { Marketing and } \\
\text { development } \\
\text { business perspective }\end{array}$ & -.084 & .331 & 1.000 & .583 & .507 & .203 & .211 & .159 & -.049 & .188 \\
\hline & $\begin{array}{l}\text { Simulations at } \\
\text { reorganizational } \\
\text { processes }\end{array}$ & .399 & .428 & .583 & 1.000 & .527 & .324 & .281 & .128 & .288 & .198 \\
\hline & $\begin{array}{l}\text { Causal connections } \\
\text { between measures }\end{array}$ & .189 & .103 & .507 & .527 & 1.000 & .503 & .180 & .198 & .357 & .517 \\
\hline & $\begin{array}{l}\text { Informational flows } \\
\text { management }\end{array}$ & .190 & .348 & .203 & .324 & .503 & 1.000 & .215 & .416 & .210 & .438 \\
\hline & $\begin{array}{l}\text { Reporting } \\
\text { for strategic } \\
\text { management }\end{array}$ & .239 & .360 & .211 & .281 & .180 & .215 & 1.000 & .516 & -.012 & .208 \\
\hline & Cost efficiency & -.131 & .161 & .159 & .128 & .198 & .416 & .516 & 1.000 & .064 & .293 \\
\hline & $\begin{array}{l}\text { Avoiding conflict } \\
\text { situations }\end{array}$ & .337 & -.160 & -.049 & .288 & .357 & .210 & -.012 & .064 & 1.000 & .537 \\
\hline & $\begin{array}{l}\text { Creative problem } \\
\text { solving }\end{array}$ & .000 & -.135 & .188 & .198 & .517 & .438 & .208 & .293 & .537 & 1.000 \\
\hline
\end{tabular}

Source: Authors’ research

connected (0.424) to identifying the goals of a particular business unit. At the same time, it was found that conflicts in a workplace has a negative effect $(-0.407)$ on a controllership's integration with the performance measurement system.

\section{Conclusions}

In analyzing the relationship between controllers’ financial knowledge and performance of restructuring programs, the correlation and dependency were statistically confirmed, thereby supporting this hypothesis. Financial knowledge plays a role as an important ingredient in formulating strategic as well as operational plans in Slovenian companies. The parallel relationship between controllers' business analytical abilities and possibilities for companies' successful turnaround was also tested. Our research provides statistical evidence from which we can confirm a significant correlation and accept this hypothesis. This fact can contribute to preparing meaningful, accurate, and useful business recommendations and reports from the needs of strategic and operational management. Although the literature describes controllership as an essential part of providing the appropriate strategic course of a company in the research, it has been found that this function is still not quite as developed as it could be expected from a theoretical standpoint. Findings about the influence of the controller's financial knowledge and business analytical competencies on overall performance of restructuring can help companies' owners and management take early actions to identify critical areas as well as necessary changes that must be taken to prevent acute crisis, liquidity, and financial unbalances that can, in the long term, lead to bankruptcy, which is commonly cited in professional literature on these issues. Both groups must consider the further integration of controllership in a management system when it comes to the questions of its analytical, consulting, and proactive role in co-creating business solutions for new economic and innovative breakthroughs, especially in the company's restructuring process. 


\section{References}

1. Altman, E. I., \& Hotchkiss, E. (2006). Corporate financial distress and bankruptcy. Hoboken, NJ: Wiley.

2. Bowman, E. H., \& Singh, H. (1993). Corporate restructuring: Reconfiguring the firm. Strategic Management Journal, 14, 5-14. Retrieved from http://www.jstor.org/stable/2486417 http://dx.doi.org/10.1002/smj.4250140903

3. Dimov, O., \& Iliev, P. (2010). Controlling-A modern system of management and control. Sofija: University of National and World Economy, Economics and Organization, 7(2), 253-262.

4. Dubrovski, D. (2011). Razsežnosti kriznega managementa. Celje: Mednarodna fakulteta za družbene in poslovne študije.

5. Keidel, R. W. (1994). Rethinking organizational design. The Academy of Management Executive, 8(4), 12-30. Retrieved from http:// www.jstor.org/stable/4165220 http://dx.doi.org/10.5465/ame.1994.9412071698

6. Linhardt, M., \& Sundqvist, S. (2004). The role of the controller. Luleal: University of Technology.

7. Maas, V. S. (2007). The effect of controller involvement in management performance measurement system gaming. Amsterdam: Faculty of Economics and Business.

8. Melavc, D., \& Novak,A. (2007). Controlling. Maribor:Založba Moderna organizacija. Univerza v Mariboru, Fakulteta za organizacijske vede Kranj.

9. Pearce, J. A., \& Robbins, K. D. (2008). Strategic transformation as the essential last step in the process of business turnaround. Business Horizons, 121-130. Retrieved from http://www.sciencedirect.com http://dx.doi.org/10.1016/j.bushor.2007.11.003

10. Perović,V., Neradžić, B., \& Todorović,A. (2012). Controlling as a useful management instrument in crisis times. Novi Sad:AJBM, 6,2101-2106.

11. Schmitt, A. (2009). Innovation and growth in corporate restructurings. Frankfurt/Main: Springer Science + Business Media. http:// dx.doi.org/10.1007/978-3-8349-9462-2

12. Smith, D. (2005). Business (not) as usual: crisis management, service recovery and the vulnerability of organisations. Journal of Services Marketing, 309-320.

13. Smith, M., \& Graves, C. (2005). Corporate turnaround and financial distress. Managerial Auditing Journal, 20(3), 304-320. http://dx.doi. org/10.1108/02686900510585627

14. Thammatucharee, Y. (2011). A financial leader's guide to enhancing long-term business stability: Controller focus model. Bangkok: Accounting and Finance Central Marketing Group.

15. Zoni, L., \& Merchant, K. A. (2007). Controller involvement in management: an empirical study in large Italian corporations. Journal of Accounting \& Organizational Change, 3(1). http://dx.doi.org/10.1108/18325910710732849

\section{Authors}

Danijel Lebar was born 1.5.1989 in Murska Sobota. As a student of business and economic science, he completed accounting, auditing, and taxation courses at the Faculty of Business and Economics in Maribor. He obtained his master's degree and completed research on the impact of controlling activities on the restructuring in Slovenian companies. As a member of Young Perspective Staff at Pomurje, he contributes to various projects and workshops under surveillance of the regional agency RRA Mura. At the same time, he was enrolled in youth exchange projects and in volunteering activities at the Voluntary Fire Brigade of Beltinci.

Iztok Kolar, Ph.D., works as an assistant professor of accounting and auditing at the University of Maribor, Faculty of Economics and Business. He is the head of the Accounting, Auditing and Taxation Institute. His main interest and topics of lecture are financial statement analysis, strategic management accounting, controllership, forensic accounting, and crime investigation in business. He has published several national and international articles and other publications (see IZUM - SICRIS, 19612).

\section{Vpliv kontrolinga na prestrukturiranje slovenskih podjetij}

\section{Izvleček}

Kontroling kot informacijska dejavnost postaja večdimenzionalna funkcija. Strateški menedžment se sprašuje, ali povečati neodvisnost kontrolinga in ga tesneje integrirati v proces sprejemanja odločitev ali ne. Finančno znanje in poslovnoanalitične sposobnosti nosilcev dejavnosti kontrolinga lahko deloma podpirajo operativno, finančno in strateško prestrukturiranje. To je pomembno pri soočanju z izzivi hitre poslovne dinamike, dvigu konkurenčnosti ter doseganju kratkoročnih in strateških ciljev.

Ključne besede: kontroling, kontrolerji, prestrukturiranje, finančno znanje, poslovnoanalitične sposobnosti 